paying for child care. Furthermore, these doctors usually work many more hours than they are paid for, they have little time for interaction with peers and with clinical teams, and elective and research sessions are vulnerable to erosion. Education often takes place out of hours, if at all. There is additional performance pressure to overcome perceived negative attitudes to part-time working.

A second rate role for women in medicine is perpetuated by the process of training, the attitudes of female doctors to each other and the politics of marriage. Currently adopted solutions force women to be more like men at work and the vulnerable situation of women may be exploited resulting in the channelling of women into unattractive specialities or geographical areas.

Dr Oates explored particular attitudes which in her view need to change; these include the attitudes of others and also of women themselves about their own abilities. For example women may tend to view themselves as facilitators rather than leaders, have difficulty in delegating and take nurturing and mothering roles at work. Overall the most important attitudinal change required is the acknowledgement of the value of home and family life and that careers in medicine should be designed to be compatible with such values.

\section{Comment}

The implications for the College are that it should promote career flexibility and part-time training opportunities for both women and men and should question and seek to rectify the absence of such opportunities. The demands of a life outside medicine, particularly those of a family, should be seen as legitimate, healthy and a positive attribute for a doctor.

One third of the members of the Collegiate Trainees' Committee (CTC) are women (Junaid, 1990). This Committee seeks to promote trainees' views within the College and has as major concerns career structure and training. It will continue to press for improvements in the career structure in psychiatry of particular relevance to women and also as part of making medicine fit to practice for doctors of either sex. In view of this, the CTC would be pleased to hear from trainees who are experiencing career problems, particularly those who are trying to balance a career with domestic commitments.

\section{References}

Allen, I. (1988) Doctors and their Careers. London: Policy Studies Institute.

A Working Party of the Collegiate Trainees' COMMITtee (1987) Part-time training in psychiatry. A brief guide to the options available. Bulletin of the Royal College of Psychiatrists, 11, 137-142.

Livingston, H. M., Ogelthorpe, D. \& Robertson, S. (1988) Part-time senior registrar training in psychiatry a feasible option? Psychiatric Bulletin of the Royal College of Psychiatrists, 12, 523-525.

Department of Health and Social Security. Joint Consultants Commitree. (1987) Hospital Medical Staffing: Achieving a Balance: Plan for Action. London: DHSS.

JuNAID, O. (1990) Working for trainees: The Collegiate Trainees' Committee. Psychiatric Bulletin, 14, 636-637.

\title{
Election of President
}

\section{Notice to Fellows and Members}

Fellows and Members are reminded of their rights under the Bye-laws and Regulations, as follows:

\section{Bye-law XI}

The President shall be elected annually from among the Fellows.

\section{Regulation XI}

(1) As soon as may be practicable after the first day of January in any year the Council shall hold a nomination meeting and shall ... nominate not less than one candidate and not more than three candidates. ...
(2) Between the first day of January in any year and the date which is four clear weeks after the nomination meeting of the Council, written nominations, accompanied in each case by the nominees' written consent to stand for election, may be lodged with the Registrar, provided that each such nomination is supported in writing by not less than twelve Members of the College who are not members of the Council.

(3) An election by ballot shall be held in accordance with the provisions of the Regulations.

The nominating meeting of the Council will be held on 15 January 1990 and the last date for receiving nominations under (2) above will therefore be 11 February 1990. Professor A. C. P. Sims is in his second year of office as President and is therefore eligible for re-election. 